\title{
REALISATION OF AESTHETIC-COGNITIVE FUNCTION OF THE READINGS IN MACEDONIAN LANGUAGE TEACHING FROM FIRST TO THIRD GRADE
}

MSc Vesna Horvatovikj, Bureau for Development of Education, Republic of Macedonia E-mail: vesnahorvatovik@bro.gov.mk

Received: October, 22.2015. Revised: December, 01.2015. Accepted: December, 10.2015. Studies and articles UDK 371.3::821.163.3

\begin{abstract}
Literary-artistic compositions, first of all, have an aesthetic function but when the same are used in the teaching they as well fulfill the cognitive function. The best "angle of view" of one literary-artistic composition in the teaching is through the balanced relation of "dolce" and "utile". The instructiveness of literary-artistic compositions in the teaching is not ultimate and should not be considered as a task that is to be performed. For the purpose of realization of these basic functions of literary-artistic compositions envisaged in the teaching, the main precondition is their appropriate selection pursuant to the age of the reading audience (the students).
\end{abstract}

Keywords: literary-artistic work, aesthetic and cognitive function of the literary-artistic work, children's literature, developmental psychology.

\section{INTRODUCTION}

"There is a judgment that can be reached with an emotion, and there is a judgment that can be reached by reasoning and drawing conclusions. They are not necessarily contradictory: emotionality can hardly acquire great critical power if it is not subjected to the common, theoretical expression of a larger dimension, and the disaggregated judgment, when it comes to literature, cannot be formed differently than on the basis of some emotion, immediate or derived" (Velek, Voren, 1985).

In the history of literature, the term reading has been interpreted differently depending on the specific historical-sociological and cultural-artistic context. The word 'lecture' originates from the French language and it denotes a reading. Primarily it denoted everything that included printed materials (books, newspapers, journals) intended for reading and for

Corresponding Author

MSc Vesna Horvatovikj, Bureau for Development of Education, Republic of Macedonia

E-mail: vesnahorvatovik@bro.gov.mk fun. In the period of the Enlightenment, the term 'lecture' was limited to works with a didactic purpose which were used in regular school classes. The works in this period were even written with a purpose, in order to teach, however, the literary criticism relativizes their aesthetic value. From today's perspective, the literary works that are being used as school readings are a selection of "masterpieces" from the world literature, which is justified from the critical and pedagogical point of view.

There are different attitudes in regard to the compulsory study of literary works in school - such claiming that literature should be solely in the function of didactics, to such claiming that it is impossible to teach without literature because its nature requires its "liberation" from the barriers of the school system. Eichenwald claims that it is impossible, and unnecessary to teach literature at school, because "literature, same as other arts, is not mandatory. It is a game and a flourishing of the spirit... Is it good to learn Tatyana's love for Onegin in a form of lesson, or that Lermontov found it boring, sad and impossible to love forever?". These views have been overcome from today's perspective, because they deny the study of literature by means of an adoption of a system of concepts, categories, and generalizations, and reduce literature to "pure personal experience".

Literary works are a symbiosis of the individual and the general; the aesthetic and the cognitive, or as Katica Kjulavkova says in her work "Longing For a System" "everything cognitive in literature is aesthetically shaped and everything that has shape is cognitive. When these two things could be separated, then one would not speak of literature" (Кулавкова, 1989).

Children's literature is in many ways more specific than "literature for adults" because it is intended for a specific readership 
to which art and game are psychologically related, so, for this reason, Lev Vygotsky in his work "Art and Life" says that "children can apply the right attitude, strange to reality, one that a fairytale requires, and in this manner they can get deep in thought of someone else's feats... in the realistic stage of their development, children lose this ability and it returns in some children in subsequent years. For this particular reason, reading the same work twice, in different periods of time, may have significant differences both in emotional and in cognitive experience.

Hence, when it comes to school reading, it is extremely important to make the proper selection of literary works for the appropriate age of students (Bognar, Matijević, 1993; Bognar, Matijević, 2002; Wortham, 2012; E. A. C. E. A. Eurydice, and Eurostat, 2014).

Inevitably a question arises: whether and to what extent the offered readings in primary school in the Republic of Macedonia evoke interest among students, to read them and to realize the general objective: acquisition of competencies for an independent reading and perception of literary works?

Therefrom, our subject of interest will be the perception of the appropriateness/inappropriateness of the selection of literary works offered as reading in terms of the aesthetic/ cognitive function and the age of the readership, as well as the relatedness with the basic concepts and objectives defined in the curriculum for the Macedonian language.

Entirely aware that we enter in a field where the intersection between literature and pedagogy is positioned, our basic objective is to consider how we can reach a balance between the two, in order to encourage the development of knowledge, skills and abilities in students, which they will apply in their studies and lives (Miller, 2008; OECD, 2008; Richards, 2001).

\section{MACEDONIAN LANGUAGE FOR PRIMARY SCHOOL AND THE TEACHING EXPERIENCE}

On the basis of the study of the curricula for the Macedonian language for primary school and the teaching experience, the findings have been confirmed, that literary works offered as reading have been planned in the curricula. These contents not only have an important educational function, but also an important teaching function. Educational functions refer to the acquisition of competencies by the students for an independent reading and writing, enriching of the vocabulary with new words, introduction to rules of written and oral expression and speech, as well as the articulation of the verbal speech. Educational functions are gradually realized by elaboration of the literary works offered as readings from an early school age of the students, between 7 and 9 years of age.

The educational functions of the readings in the curricula for the Macedonian language in primary school are not separated from the other integrative functions. The study of literary works offered as reading in our schools and in other countries, the curricula and the programs, as well as the experience in teaching, all show that depending on the theme, the language and the style of the readings, as well as the motivation of the students and the teacher, other teaching integrative functions can also be achieved, such as:

- to arouse curiosity in students, as well as emotional experience and thinking about the themes and the motives of the literary works offered as reading;

- students become familiar with the genre diversity of the literary creation;

- students adopt literary theoretical concepts;

- the attention and the interest in literaryaesthetic values of literary works are aroused in students;

- a foundation is created, and the interests in artistic expression and creation are developed;

- reading culture is developed;

- the vocabulary of students is enriched;

- rules for oral and written expression are adopted.

However, experience shows that the indicated functions can be realized if the literary works offered as reading corresponds to the age and the developmental characteristics of the students. For these reasons, we decided to make an overview of the type of literary works offered as reading in the curricula for the Macedonian language in the first period (from first to third grade), as well as an analysis of the themes, the style and the language of the literary works offered as readings. The contributions of this analysis are directed towards consideration of the correlations between the specific objectives, concepts, and contents from the curriculum with the literary works offered as school readings, as well as the themes, the style and the language of the literary works with the teaching and other integrative functions. Our findings are system- 
atized and presented according to the age of students in the nine-year primary education (first developmental period: from first to third grade).

\section{MACEDONIAN LANGUAGE IN THE FIRST DEVELOPMENTAL PERIOD}

The subject Macedonian language in the first developmental period of the nineyear primary education is being taught in 5 lectures per week. The teaching contents for this subject are divided into several fields: listening and speaking, literature, expression and creation, media culture, preparation for initial reading and writing - in first grade, while in second grade the fields are supplemented by the field of language, and the field of preparation for initial reading and writing is called initial reading and writing. The contents are divided within the same fields in third grade as well.

In the part named Literature, the students in first grade have the objective to adopt the teaching contents: story, fable, fairy tale, poem, drama text, riddle, tongue twisters. Within the same field in second grade, they should adopt the following contents: title, name of author, content, and illustration - of a book, song, poem, drama text, saying, riddle, tongue twister, reading - aloud, expressively and silently, and in the second semester they should elaborate three readings. In third grade the students should adopt the terms (and their meanings) character, the sequence of events, sayings and riddles, poem, verse, strophe, rhyme, and they should recognize a story, a fairy tale, a fable and drama text. In order to adopt these contents and concepts, one should approach towards the realization of the objectives for the acquisition of competencies for reading and experiencing contents from texts, and students should acquire competencies to read aloud, expressively and silently.

From what is indicated, and from the table below, one can see that in the first developmental period of the primary education, that is, in the period from first to third grade, the students become familiar with the popular literature: story, fairytale, fable, and we must mention that they may be also written by an author, and the short popular intellectual creations - riddles, tongue twisters, children's rhymes (some of them are also written by an author), then the poems/songs and the basic characteristics of poetry, and drama texts.
During the elaboration of these types of prose and poetry works, the students learn and initially master the reading skill, and then they also understand the contents they read, thereby they become literate in regard to the basic determinants of each written text: time, space, character, event, the sequence of events.

In accordance with what is indicated above, and pursuant to the curriculum for the subject Macedonian language, in addition to the adoption of these contents and mastering of the mentioned objectives, an elaboration of three, that is, four readings has been stipulated for the second and third grade. From the current and consolidated list of readings (provided as an attachment), it is evident that in second grade one fairytale has been stipulated, and one collection of stories, a selection of poems and one optional work from the Macedonian production or more specifically, "Snow-White" by the Grimm Brothers, "Zoki Poki" by Olivera Nikolova, "Poems" by Vasil Kunovski (selection according to age), and an optional work from Macedonian literature. The fairytale and the poems are correlated with the educational contents and concepts that have been stipulated for second grade. A story has not been stipulated as a teaching content in this grade, however, the content of the stories about the hero Zoki Poki are in accordance with the developmental needs of the students. The volume of pages for reading is slightly high for this age because the acquisition of literacy by students takes places in second grade. The optional work from the Macedonian production is a too expensive option and in this regard, it is necessary to propose several titles of which the teacher would make a particular choice.

The reading works for third grade include: "Stories" by Leo Tolstoy, "Doctor Aybolit" by Korney Chukovsky, Magical stories from the Slavic people, "Poems" by Vasil Kunovski (selection according to age) and an optional work from the Macedonian literature. The students in this grade do not define and do not work on a story from a narratological point of view, also, a novel, hence the "Stories" of Tolstoy and the novel "Doctor Aybolit" are works that are being elaborated only as stories on a specific theme. "The Magical Stories" are being elaborated as a replacement for fairytales or in general as fiction stories. Careful analysis and elaboration should be performed in regard to the contents of part of these stories, And again, in this grade, poems by $\mathrm{Ku}-$ novski are included, optionally, to supplement poetry, that is, the poems that have been stipu- 
lated for mastering the literary concept. As we have already mentioned above, in regard to the optional work from the Macedonian production, there is an extensive list of options and in this regard, it is necessary to propose several titles of which the teacher would make a particular selection.
Further, on there is a tabular presentation of the objectives, the contents and the activities stipulated with the Curriculum for the subject Macedonian language for first, second and third grade.

Table 1. Objectives, contents and activities stipulated with the Curriculum for the subject Macedonian language for first, second and third grade

\begin{tabular}{|c|c|c|c|c|}
\hline First grade & Contents & Concepts & $\begin{array}{l}\text { Activities and } \\
\text { methods }\end{array}$ & Stipulated readings \\
\hline $\begin{array}{l}\text { Becomes familiar } \\
\text { with children's } \\
\text { literature; } \\
\text { Acquires } \\
\text { competences to } \\
\text { listen and experience } \\
\text { contents of texts, } \\
\text { recognizes literature } \\
\text { elements (event, } \\
\text { character, time), } \\
\text { determines the } \\
\text { meaning of the } \\
\text { literary works. }\end{array}$ & $\begin{array}{l}\text { Story, fable, } \\
\text { fairytale, poem, } \\
\text { drama text, riddles, } \\
\text { tongue twisters. }\end{array}$ & $\begin{array}{l}\text { Story, fable, } \\
\text { fairytale, poem, } \\
\text { drama text, riddles, } \\
\text { tongue twisters. }\end{array}$ & $\begin{array}{l}\text { Elaboration of a } \\
\text { story, fable, } \\
\text { fairytale, drama text } \\
\text { (more of each type } \\
\text { of indicated work), } \\
\text { poems, riddles, } \\
\text { tongue twisters. } \\
\text { Exercises for space, } \\
\text { time, course and } \\
\text { sequence of events. }\end{array}$ & l \\
\hline Second grade & & & & \\
\hline $\begin{array}{l}\text { Acquired } \\
\text { competences to; } \\
\text { make a difference } \\
\text { between a title, a } \\
\text { text, an illustration, } \\
\text { events and } \\
\text { characters, acquires } \\
\text { competences to read } \\
\text { poetry, acquires } \\
\text { competences to read } \\
\text { aloud and to read } \\
\text { silently, and } \\
\text { understands } \\
\text { readings. }\end{array}$ & $\begin{array}{l}\text { Reading: aloud, } \\
\text { expressively, and } \\
\text { silently. Title, name } \\
\text { of author, content } \\
\text { and illustration, } \\
\text { song, poem, drama } \\
\text { text, proverb, riddle, } \\
\text { tongue twister, } 3 \\
\text { readings to elaborate }\end{array}$ & $\begin{array}{l}\text { Title, name of } \\
\text { author, content and } \\
\text { illustration, song, } \\
\text { poem, drama text, } \\
\text { proverb, riddle, } \\
\text { tongue twister. }\end{array}$ & $\begin{array}{l}\text { Exercises for } \\
\text { reading and retelling } \\
\text { of prose and poetry } \\
\text { works, exercises for } \\
\text { determination of the } \\
\text { theme and message } \\
\text { of a text, motivation } \\
\text { for an independent } \\
\text { reading g of literary } \\
\text { works }\end{array}$ & $\begin{array}{l}\text { "Snow-White" by } \\
\text { Grimm Brothers } \\
\text { (corresponds with } \\
\text { the curriculum), } \\
\text { "Zoki Poki" in } \\
\text { Olivera Nikolovska, } \\
\text { "Poems" by Vasil } \\
\text { Kunovski (selection } \\
\text { according to the } \\
\text { age), pursuant to the } \\
\text { curriculum Optional } \\
\text { work from the } \\
\text { Macedonian } \\
\text { literature }\end{array}$ \\
\hline Third grade & & & & \\
\hline $\begin{array}{l}\text { Acquires } \\
\text { competences to read: } \\
\text { aloud, silently, } \\
\text { expressively. } \\
\text { Acquires } \\
\text { competences to } \\
\text { determine } \\
\text { characters, } \\
\text { description, events, } \\
\text { contents; Acquires } \\
\text { competences to } \\
\text { make a difference } \\
\text { between riddles, } \\
\text { proverbs and poetry, } \\
\text { and distinction from } \\
\text { other types of texts. }\end{array}$ & $\begin{array}{l}\text { Reading aloud, } \\
\text { expressively, } \\
\text { silently, drama } \\
\text { reading, literary } \\
\text { character, sequence } \\
\text { of events, proverbs } \\
\text { and riddles, poem } \\
\text { (verse, strophe, } \\
\text { rhyme), } 4 \text { books for } \\
\text { reading }\end{array}$ & $\begin{array}{l}\text { Character, sequence } \\
\text { of events, proverbs } \\
\text { and riddles, poem } \\
\text { (verse, strophe, } \\
\text { rhyme) }\end{array}$ & $\begin{array}{l}\text { Exercises for } \\
\text { reading aloud and } \\
\text { logical reading, } \\
\text { exercises for } \\
\text { recognition of a } \\
\text { story, fairytale, fable } \\
\text { and drama text, } \\
\text { content structure of } \\
\text { texts. Exercises for } \\
\text { description of a } \\
\text { character, exercises } \\
\text { for learning and use } \\
\text { of riddles and } \\
\text { proverbs, exercises } \\
\text { for a verse, strophe } \\
\text { and rhyme. }\end{array}$ & $\begin{array}{l}\text { "Stories" by Leo } \\
\text { Tolstoy, "Doctor } \\
\text { Aybolit" by Komey } \\
\text { Chukovsky, } \\
\text { "Magical Stories" } \\
\text { from the Slavic } \\
\text { people, pursuant to } \\
\text { the curriculum } \\
\text { "Poems" by Vasil } \\
\text { Kunovski (selection } \\
\text { according to the } \\
\text { age), pursuant to the } \\
\text { curriculum, optional } \\
\text { work from the } \\
\text { Macedonian } \\
\text { literature }\end{array}$ \\
\hline
\end{tabular}




\section{DISCUSSIONS}

Considering that the overview is systematized according to the age of students, a possibility is provided to perceive the relations between the readings and the next components in the teaching and education of students, as follows:

a) In terms of the harmonious development of students:

- development of awareness in students about their personal individuality, encouraging self-confidence and responsibility;

- teaching to respect human rights, gender equality and fundamental freedoms for living in a democratic society;

- development of communication skills, critical thinking, and creativity of students;

- development of abilities to recognize personal feelings and to understand the feelings of others;

- promotion of the importance of learning and work;

- acquisition of competencies by students to evaluate their progress.

b) In regard to acquisition of competencies by students to adopt a system of knowledge and skills:

- adoption of general and applicable knowledge that is necessary for everyday life;

- adoption of knowledge in the field of Macedonian language and the theory of literature;

- encouragement of intellectual curiosity, sense of beauty and a research spirit in students;

- encouragement of creativity and abilities to express oneself.

c) In regard to the development of civic awareness among students:

- familiarization with the past and the cultural traditions of the Macedonian people, the past and the cultural traditions of other people and cultures;

- promotion of the principle of equality between people regardless of their origin or orientation;

- promotion of the importance of tolerant behavior, solidarity and acquisition of competencies for non-violent conflict resolution.

\section{CONCLUSIONS}

This methodological approach in the study of the contents of readings creates a theoretical framework that contains important elements for the literary-aesthetic values of reading and didactic components that are the subject matter of our research in regard to the treatment of speech development and communication skills in preschool children and early school-age children.

\section{Conflict of interests}

Author declare no conflict of interest.

\section{REFERENCES}

Bognar, L., Matijević, M. (1993). Didaktika. Školska knjiga, Zagreb.

Bognar, L., Matijević, M. (2002). Didaktika II izmenjeno izdanje. Školska knjiga, Zagreb.

EuropeanCommission, E. A. C. E. A. Eurydice, and Eurostat (2014):"Key data on Early Childhood Education and Care in Europe,". Eurydice and Eurostat Report.

К̈улавкова, К. (1989). Копнеж по систем. Македонска книга, Скопје.

Miller, D. (2008). Teaching with intention: Defining beliefs, aligning practice, taking action, K-5. Stenhouse Publishers.

OECD. (2008). Trends shaping education. OECD Centre for Educational Research and Innovations, Paris.

Richards, J. C. (2001). Curriculum development in language teaching. Ernst Klett Sprachen.

Velek, R., Voren, O. (1985). Teorija književnosti. Nolit, Beograd.

Wortham, S. C. (Ed.). (2012). Common characteristics and unique qualities in preschool programs: Global perspectives in early childhood education (Vol. 5). Springer Science \& Business Media. 
(IJCRSEE) International Journal of Cognitive Research in Science, Engineering and Education Vol. 3, No.2, 2015. 